\title{
Konaklama İşletmelerinde Psikolojik Sözleşme ỉhlali ve Örgütsel Özdeşleşmenin Sonuçları: Eşitlik Duyarııı̆ının Aracı Rolü
}

The Consequences of Psychological Contract Breach and Organizational Identification in Accommodation Enterprises: The Mediating Role of Equity Sensitivity

\author{
Bekir EŞiTTi* \\ *Dr., Çanakkale Onsekiz Mart Üniversitesi, Turizm Fakültesi, Seyahat İşletmeciliği ve Turizm Rehberliği Bölümü, Terzioğu Kampüsü, 17020, Çanakkale. \\ E-posta: bekiresitti@comu.edu.tr \\ ORCID: 0000-0002-5240-9233
}

MAKALE BILGILERI

Makale işlem bilgileri:

Gönderilme tarihi: 2 Haziran 2017

Düzeltme: 26 Temmuz 2017

Düzeltme: 7 Eylül 2017

Kabul: 10 Eylül 2017

Anahtar sözcükler: Eşitlik duyarlılığ $l_{\text {, }}$ Psikolojik sözleşme ihlali, Örgütsel özdeşleşme, Duygusal bağhlik, İş performansı.

\section{ARTICLE INFO}

Article history:

Submitted: 2 June 2017

Resubmitted: 26 July 2017

Resubmitted: 7 September 2017

Accepted: 10 September 2017

Key words: Equity sensitivity, Perceived psychological contract breach, Organizational identification, Emotional commitment, Job performance.

\section{ÖZ}

Bu çalışmanın amacı, konaklama işletmeleri çalışanlarının psikolojik sözleşme ihlali ve örgütsel özdeşleşme algılarının duygusal bağılıık ve iş performansı üzerindeki etkilerini açıklamaya çalışmak ve psikolojik sözleşme ihlali ile iş performansı arasındaki ilișkide eșitlik duyarııı̆ının aracı rolünü incelemektir. Örnekleme yöntemi olarak tesadüfi olmayan örnekleme yöntemlerinden kolayda örnekleme yöntemi kullanılarak, İstanbul ve Antalya illerindeki beş yıldızlı konaklama işletmeleri çalışanlarına 2017 Ocak-Mart ayları içerisinde anket uygulanmıştır. Çalışmada, değişkenler arasındaki etkileri ölçmek amacıyla yapısal eşitlik modelinden yararlanılmıștır. Araștırma sonucunda, psikolojik sözleșme ihlalinin çalışanların eșitlik duyarlılığını, duygusal bağılığını, örgütsel özdeşleşme ve iş performansını olumsuz yönlü etkilediği tespit edilmiştir. Örgütsel özdeşleşmenin ise konaklama işletmeleri çalışanlarının iş performansını artırdığı sonucuna ulaşıımıştır. Bu çalışma ile ayrıca, psikolojik sözleșme ihlalinin, is performansına olumsuz etkisi üzerinde eșitlik duyarlıı̆̆ının kısmi aracı rolünün varlığı saptanmıștır. Bununla birlikte eșitlik duyarlıığının duygusal bağıılık üzerinde anlamlı bir etkisinin olmadığı sonucuna ulaşılmıştır.

\section{Giriş}

Blau'nun (1964) Sosyal Değişim Teorisi, Adams'ın (1965) Eşitlik Teorisi ve Gouldner'un (1960) Karşılıklılık Teorisi'ne dayanan bir kavram olan psikolojik sözleşme kavramı örgütsel alanda araştırmacıların dikkatini çeken ve turizm işletmelerinde yürütülen araştırmalarda da (Blomme vd. 2010; Lub vd. 2012; Wu ve Chen 2015; Li, Wong ve Kim 2016) incelenen bir konudur. Psikolojik sözleşme, çalışanların kendilerinden hangi eylemlerin beklendiğine ve karşılığın- da ne beklemeleri gerektiğine ilişkin inançlarını (Rousseau ve Greller 1994: 385) ifade eden, bunun yanında işvereni ve iş göreni, beklentiler ve sonuçlar açısından birbirine bağlayan (Turnley vd. 2003; Blomme vd. 2010; Li vd. 2016) alg1sal bir unsurdur. Kavram aynı zamanda, çalışanların işin gereklerine ulaşma yönünde çaba harcamasını yansıttı̆̆ından, örgüt amaçlarıyla da yakından ilgilidir.

Alanyazında psikolojik sözleşme ve bu sözleşmeye uyulmamasını ifade eden psikolojik söz- 
leşme ihlalini (Dulac vd. 2008), örgütsel bağlılık (Raja vd. 2004), örgütsel vatandaşlık davranışı (Shih ve Chuang 2013), işten ayrılma niyeti (Dulac vd. 2008) gibi pek çok faktörle ilişkilendirerek inceleyen çalışmalar mevcuttur (Lub vd. 2012; Wu ve Chen 2015). Bu faktörlerin büyük ölçüde çalışanların iş performansı gibi davranışsal tepkileri ile ilişkili olduğu görülmektedir. Psikolojik sözleşme ihlalinin örgütsel özdeşleşme aracıllğıyla iş performansı üzerindeki etkisini ele alan az sayıda çalışma (Epitropaki 2013) olmasının yanında, özdeşleşme ve performans ilişkisini kavramsal ve ampirik olarak inceleyen çalışmalar mevcuttur (Ashforth vd. 2008; Galvin vd. 2015).

Psikolojik sözleşme ihlali ve örgütsel özdeşleşme ile ilgili ulusal ve uluslararası alanyazında, 1994-2017 yılları arasında gerçekleştirilen birçok çalışma olmasına rağmen bu konuların çalışanların eşitlik duyarlılığı, duygusal bağlılıkları ve iş performansları üzerindeki etkilerini birlikte araştıran bir çalışmaya rastlanamamıștır. Bununla birlikte, bu araştırma psikolojik sözleşme ihlalinin iş performansı üzerindeki etkisinde eşitlik duyarlılığının aracı rolünü ele alması bakımından önem taşımaktadır. Bu önem itibari ile uygulamada, eşitlik duyarlılığına dikkat edildiğinde psikolojik sözleşme ihlalinin azalacağı ve doğru orantılı olarak çalışanların iş performansının artacağı savının destekleneceği bahsedilen araştırmalardan yola çıkılarak düşünülmektedir. Bu bağlamda çalışmanın amacı psikolojik sözleşme ihlali ve örgütsel özdeşleşmenin duygusal bağlılık ve iş performansı üzerindeki etkilerini açıklamaya çalışmak ve psikolojik sözleşme ihlali ve iş performansı arasındaki ilişkide eşitlik duyarlılığının aracı rolünü araştırmaktır. Bu amaç doğrultusunda, alanyazın dikkate alınarak oluşturulan araştırma modeli yapısal eşitlik modeli ile test edilmiştir.

\section{KAVRAMSAL ÇERÇEVE}

\section{Psikolojik Sözleşme İhlali}

Psikolojik sözleşme, bir kişi ile diğer taraf arasında karşılıklı değişim sözleşmesinin hüküm ve koşulları hakkında sahip olunan inancı ifade etmesinin yanında, resmi sözleşmelerin aksine algisal bir sözleşmedir (Li vd. 2016). Örgütte, ça- lışanı ve işvereni birbirine bağlayan yazılı şekle gelmemiş karşılıklı bir anlaşmayı tanımlayarak; çalışanın ve işverenin rollerini ve beklentilerini, bunun karşılığında yükümlülüklerini ve kazanımlarını da belirleyici etkisi olan bir anlaşmadır (Tekleab vd. 2005).

Psikolojik sözleşmede tarafların sorumluluklarını ve yükümlülüklerini yerine getirmesi son derece önem taşımaktadır. Bu algısal sözleşmede "işverenin sözleşmenin unsurlarından bir veya birkaçını yerine getirmede başarısız olması" psikolojik sözleşme ihlali olarak (Morrison ve Robinson 1997: 230) tanımlanır. İhlal alg1sı, "her iki tarafın vaatleri ve gerçekleştirdikleri konusunda çalışanların algılarına dayanan gerçekleştirmenin bilişsel değerlendirilmesi" olarak tanımlanmaktadır (Morrison ve Robinson 1997: 230; akt. Şahin Perçin vd. 2012: 95). Psikolojik sözleşme ihlali, çalışanların bilişsel bir değerlendirmesidir. Psikolojik sözleşme ihlali kavramı, çalışanların tutum ve davranışlarını şekillendiren temel faktör olması sebebi ile işveren-işçi ilişkilerinin (Lub vd. 2012) araştırılmasında yaygın olarak kabul edilmiştir. İşverenin yükümlülüğünü yerine getirmemesi; çalışanların iş memnuniyetsizliği, işten ayrılma niyeti gibi olumsuz davranışlar geliştirmesi ile sonuçlanabilir (Tekleab vd. 2005).

Wu ve Chen (2015), Tayvan'da otellerde gerçekleştirdikleri araştırmada psikolojik sözleşmenin yerine getirilmesinin, bilgi alışverişi ve servis performansı ile olumlu ilişkisinin olduğunu tespit etmişlerdir. Aynı şekilde, çalışanların örgütsel kuralları dikkate alan çalışma tutumu göstermeleri (Conway vd. 2011), örgütün misyonuna ve faaliyetlerine bağlilık göstermeleri (Allen ve Meyer 1990), özel rol davranışlarını ve işin gereklerini yerine getirmeleri beklenir (Turnley vd. 2003).

Ampirik araştırmalar, psikolojik sözleşme alg1sının yerine getirilmesi ile çalışanların genellikle işe karşı olumlu tutum gösterdiklerini (Conway vd. 2011), bu çalışanların örgütü kucaklamaya eğilimli olduklarını, bunun yanında örgütsel vatandaşlık davranışları ve örgütsel bağlılık (Lester vd. 2000), iş performansı ve diğer rol davranışlarının arttığını (Turnley vd. 2003) ortaya koymuştur. Ayrıca, psikolojik sözleşme ihlali, örgüt- 
sel sinizm ve örgütsel vatandaşlık davranışlarını (Shih ve Chuang 2013), özveri, iş tatmini ve örgütsel bağlllığı azaltan (Conway vd. 2011), işten ayrilma niyetini arttıran (Dulac vd. 2008) bir kavram olarak pek çok olumsuz sonuçla ilişkilidir. Dulac vd. (2008) psikolojik sözleşme ihlali ile işten ayrılma niyeti ve iş performansı değişkenleri arasında doğrudan bir ilişki tespit etmiş, benzer şekilde Li ve arkadaşları (2016), psikolojik sözleşme ihlalinin çalışanların bilişsel ve duygusal rol performanslarını yansıtan örgütsel özdeşleşme ve duygusal bağlllık üzerine etkilerini incelemiştir. Bahsedilen çalışmalar ışığında bu çalışmanın amacı, konaklama işletmeleri çalışanlarının psikolojik sözleşme ihlali algılarının duygusal bağlılık ve iş performansı üzerindeki etkilerini araştırmak ve psikolojik sözleşme ihlalinin iş performansı ile arasındaki ilişkide eşitlik duyarlılığının aracı rolünü incelenmektir.

\section{Örgütsel Özdeşleşme ve Duygusal Bağlılık}

Özdeşleşme kavramı, örgütsel olaylarda yer alan temel yapılardandır ve çok sayıda örgütsel davranışın alt konularını oluşturmaktadır (Albert vd. 2000: 13). Özdeşleşme, örgüt üyelerinin kendilerini örgütü temsil eden çalışan olarak görmesi şeklinde tanımlanır (Kreiner ve Ashforth 2004). Ashforth ve Mael (1989: 23) örgütsel özdeşleşmeyi, "başarı ve başarısızlık durumlarını da içeren, ait olma ya da birlik olma algılayışı" olarak tanımlarken, Dutton ve arkadaşları (1994: 193) "kişinin kendisi ile örgütü tanımlaması arasındaki bilişsel bağ" olarak tanımlamıştır. Örgütsel özdeşleşme, örgütün özelliklerinin ve başarısının bireyin benlik kavramının içine dahil edildiği, örgüte olan ilgiyi ifade eden (Dutton vd. 1994), bireyin davranışları üzerinde önemli etkilerde bulunduğu kabul edilen bir kavramdır (Lu vd. 2016).

Özdeşleşmenin, bireysel, grup ve örgütsel düzeyde önemli etkileri vardır (Kreiner ve Ashforth 2004). Bartel (2001), Pillsbury topluluğu çalışanları üzerine gerçekleştirdiği çalışmasında örgütsel özdeşleşmenin, performans ve örgütsel vatandaşlık davranışları ile olumlu, işten ayrılma niyeti ve gerçekleşen işten ayrılma ile olumsuz ilişkisinin olduğunu saptamıştır.
Epitropaki (2013), banka personelinin örgütsel özdeşleşmeyle psikolojik sözleşme ihlaline karş1 koyduğunu tespit etmiştir. İşverenler sözlerini yerine getirmediklerinde ise çalışanların duygusal bağlılıkları azalmaktadır. Bunun yanında, konaklama endüstrisinde Lub vd. (2012) tarafından gerçekleştirilen çalışmada, işverenlerin vaatlerini yerine getirmedeki ihlalleri konaklama çalışanları tarafından görüldüğünde, çalışanların duygusal bağll1ığında düşüş yaşanmakta ve nihayetinde işten ayrılmalar gerçekleşmektedir. Benzer bir sonuçta Li vd. (2016) Çin'de otel işletmelerinde yaptıkları çalışmada da psikolojik sözleşme ihlalinin örgütsel özdeşleşme ve duygusal bağll1ığ1 azalttığını göstermiştir.

Bu çalışmada, bahsedilen görgül araştırmalardan yola çıkarak psikolojik sözleşme ihlalinin örgütsel özdeşleşme ve duygusal bağll1ık üzerinde olumsuz bir etkiye sahip olduğu varsayılmıştır.

$\mathrm{H}_{1}=$ Psikolojik sözleşme ihlali otel çalışanlarının örgütsel özdeşleşmesini olumsuz yönde etkiler.

$\mathrm{H}_{2}=$ Psikolojik sözleşme ihlali otel çalışanlarının duygusal bağlılığını olumsuz yönde etkiler.

\section{Eşitlik Duyarlııı̆ı}

Eşitlik teorisine göre bireyler, girdileri (çaba, eğitim, performans kalitesi gibi) ile bunun karşıl1ğında elde ettikleri sonuçlar (iş unvanı, ödeme gibi) arasında diğer bireylerle bir karşılaştırma yaparlar (Adams 1965). Denklik duyarlılığı kavramı, insanların eşitsizlik durumuna farklı tepkiler göstermesine neden olan kişilik özelliklerine bir örnektir. Eşitlik duyarlılığı, kişinin neyin eşit olduğuna veya olmadığına ilişkin algısıdır. Huseman (1987), bireylerin eşit olmayan değiş-tokuşlara verdikleri tepkilerle ilgili araştırmalardaki bu çelişkili sonuçları açıklayabilmek amacıyla eşitlik duyarlılığı kavramını geliştirmiş ve üç farklı türe ayırmıştır. Geleneksel Eşitlik Kuramı'nın önerdiği model çerçevesinde davranan eşitliğe duyarlı tipler, eşitliği yatırımların sonuçlardan fazla olması olarak algılayan verici tipler; eşitliği yatırımların sonuçlardan az olması olarak algılayan alıcı tiplerdir (Atalay 2007).

Kısaca, örgütler eşitlik duyarlılığı yardımı ile psikolojik sözleşme ihlali, iş tatmini ve örgütsel 
vatandaşlık davranışını yönetebilmektedir. Psikolojik sözleşme çok boyutludur ve bu sözleşmenin çok boyutlu bileşenleri arasında eşitlik duyarlılığının rolünün incelenmesi gerekir (Kickul ve Lester 2001).

Eşitlik teorisi perspektifinde bireyler örgütten aldıkları ile örgüte verdikleri katkı arasındaki adil dengeyi bulmaya çalışırlar. Çalışanlar, işverenin vaatlerini yerine getirmediğini algıladıkları zaman yaptıkları katkıda kesintiye giderler (Morrison ve Robinson 1997). Shore ve Barksdale (1998), çalışanlar ile işverenler arasındaki yükümlülüklerin yüksek olduğu algılandığında örgütsel destek ve duygusal bağlllığın yüksek olduğunu, iş gören devir hızının düşük seviyelerde gerçekleştiğini tespit etmişlerdir.

Bu kapsamda yapılan görgül araştırmalardan yola çıkarak; eşitlik duyarlılığının örgütsel özdeşleşme ve duygusal bağlllık üzerinde olumlu bir etkiye sahip olduğu ve psikolojik sözleşme ihlalinin eşitlik duyarlılığı üzerinde olumsuz bir etkiye sahip olduğu varsayılmıştır.

$\mathrm{H}_{3}=$ Eşitlik duyarlılığı, konaklama işletmeleri çalışanlarının örgütsel özdeşleşmesini olumlu yönde etkiler.

$\mathrm{H}_{4}=$ Eşitlik duyarlılığı, konaklama işletmeleri çalışanlarının duygusal bağlılığını olumlu yönde etkiler.

$\mathrm{H}_{5}=$ Psikolojik sözleşme ihlali, eşitlik duyarlılığını olumsuz yönde etkiler.

\section{İş Performansı}

Çalışanlar, yüksek özdeşleşme koşulları altında, örgütün başarısı ve etkinliği için endişe hissederek çaba gösterirler (Dutton vd. 1994). Nitekim örgütsel özdeşleşmesi yüksek olan çalışanlar, iş rollerini daha az kısıtlı olarak tanımlar ve örgüt yararına faaliyetlerle daha fazla ilgilenirler (Van der Vegt vd. 2003). Örgütü ile güçlü bir şekilde özdeşleşen bireylerin, performanslarını arttırmak ve örgütün çıkarına hizmet edeceği ve bunu yaparken de öz saygılarının güçleneceği olasıdır (Ashforth ve Mael 1989: 2005). Turizm işletmelerinin faaliyetlerinin başarısı, müşterilerine yüksek kaliteli hizmet sunumuna bağlıdır. Örgütü ile özdeşleşme bağı güçlü olan çalışanların per- formanslarının ötesinde çaba harcamaları muhtemeldir (Ashforth vd. 2008). Bu çalışanlar sadece yapmaları gereken görevleri üstlenmeyip, aynı zamanda bağlılığı düşük meslektaşlarının performansından daha iyi performans göstermektedirler (Heskett vd. 1994). Li ve arkadaşları tarafından (2016) Çin'de otel işletmelerinde gerçekleştirilen araştırmada da örgütsel özdeşleşmenin iş performansı üzerinde olumlu etkisinin olduğu saptanmıştır. Çalışma kapsamında bahsedilen görgül araştırmalardan yola çıkarak, psikolojik sözleşme ihlalinin iş performansı üzerinde olumsuz bir etkiye sahip olduğu varsayılmıştır.

$\mathrm{H}_{6}=$ Psikolojik sözleşme ihlali otel çalışanlarının iş performansını olumsuz yönde etkiler.

$\mathrm{H}_{7}=$ Otel çalışanlarının örgütsel özdeşleşme alg1ları iş performanslarını olumlu yönde etkiler.

$\mathrm{H}_{8}=$ Psikolojik sözleşme ihlalinin otel çalışanlarının iş performanslarına olumsuz etkisinde eşitlik duyarlılı̆̆ının aracı rolü vardır.

\section{YÖNTEM}

Araştırmada nicel araştırma yöntemi kullanılmiş, veriler anket tekniği ile elde edilmiştir. Anket formunun hazırlanmasında, daha önce geçerlilik ve güvenilirliği test edilmiş ölçekler kullanılmiştır.

\section{Araştırmanın Modeli}

Bu çalışmada, konaklama işletmeleri çalışanlarının psikolojik sözleşme ihlali ve örgütsel özdeşleşme algılarının duygusal bağlılık ve iş performansı üzerindeki etkileri araştırılmakta ve psikolojik sözleşme ihlali ile iş performansı arasındaki ilişkide eşitlik duyarlılığının aracı rolü incelenmektedir. Örgüt içinde psikolojik sözleşme ihlali, çalışanın örgüte ait olma ya da örgütle birlik olma ve diğer çalışanlarla eşit olma algısını zedelemekte, duygusal bağlılığı azaltmakta ve performans olarak çalışanın güçsüzleşmesine neden olabilmektedir. Konaklama işletmeleri çalışanlarının, iş ortamında algıladıkları eşitlik duyarlılığ da örgütsel özdeşleşmelerini, duygusal bağlılıklarını ve iş performanslarını etkileyebilmektedir. Bu düşünceden hareketle bu çalışmanın odağı, çalışanların psikolojik sözleşme ihlali algılarının 


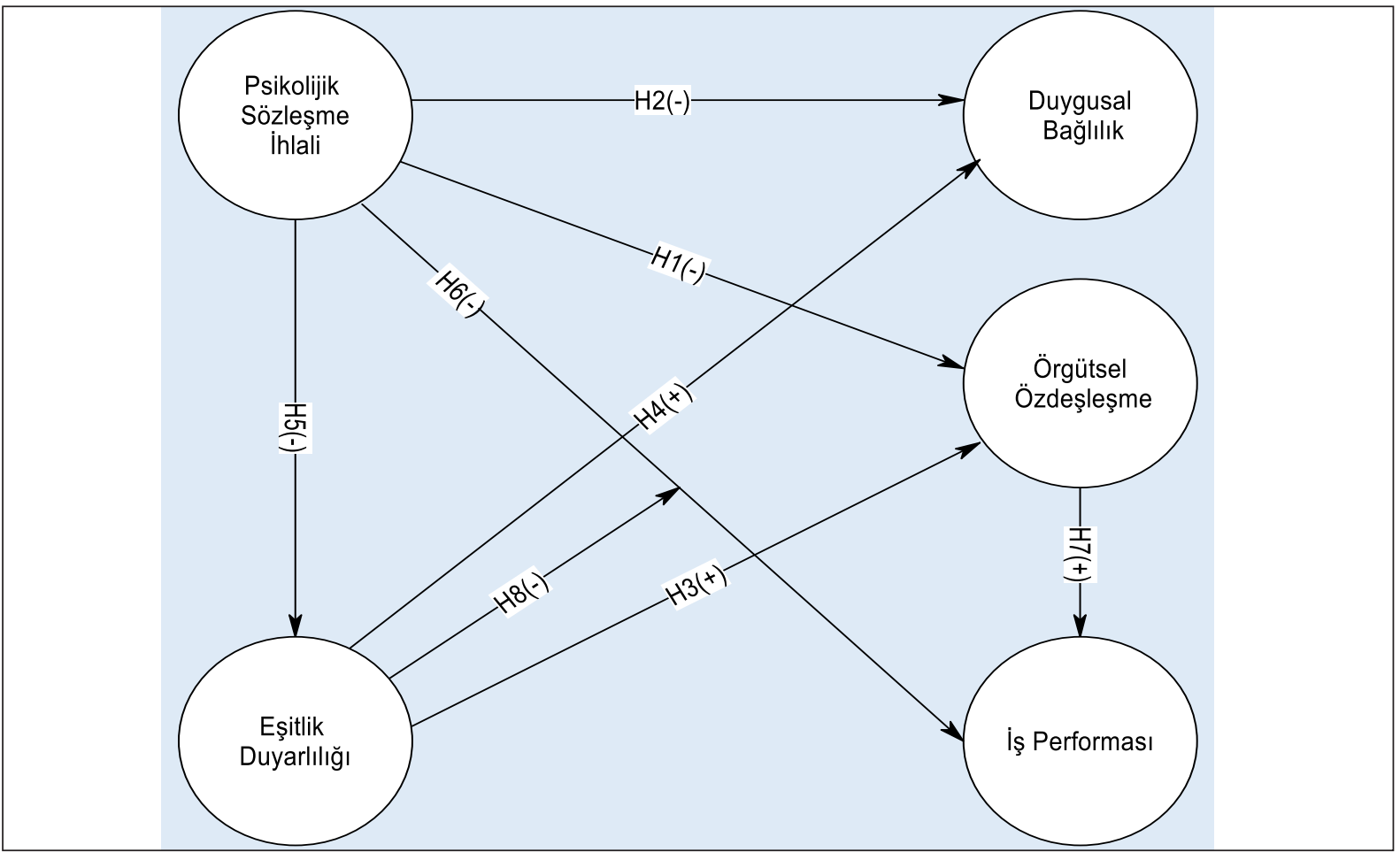

Sekil 1. Araştırma Modeli

iş performanslarına etkisinde eşitlik duyarlılığının aracı rolünü sınamaktır. Bu bağlamda araştırmanın modeli, aşağıdaki şekildedir.

\section{Araştırmada Kullanılan Ölçekler}

Psikolojik sözleşme ihlali, Robinson ve Morrison (2000) tarafından geliştirilen ve dokuz ifadeden oluşan psikolojik sözleşme ihlali ölçeği ile ölçülmüştür. Örgütsel özdeşleşmenin belirlenmesinde Mael ve Ashforth (1992) tarafından geliştirilen ve pek çok araştırmada kullanılan (Örn. Mael ve Tetrick 1992; Mael ve Ashforth 1992; Turunç ve Çelik 2010) altı madde ve tek boyuttan oluşan Örgütsel Özdeşleşme Ölçeği kullanılmıştır. Çalışanların eşitlik algısını tespit etmek için Sauley ve Bedeian'dan (2000) uyarlanan 16 maddelik Eşitlik Önceliği Ölçeği (Equity Preference Questionnaire) kullanılmıştır. Duygusal bağlılığı ölçmek için Allen ve Meyer' in (1990) üç boyutlu örgütsel bağlılık modelinde yer alan (duygusal, devamlılık ve normatif) boyutlardan Duygusal Bağlllık boyutu kullanılmıştır. Çalışanların performanslarını ölçmek amacıyla Sigler ve Pearson'un (2000) çalışmalarında kullandığı dört maddelik İşgören Per- formans Ölçeği kullanılmıştır. Seçilen evrenden veri toplanmadan önce, oluşturulan anket arac1nın geçerli ve güvenilir olduğundan emin olmak için pilot test gerçekleştirilmiştir. Pilot test için örneklem büyüklügü normalde küçüktür ve 1530 katılımcı arasında değişir ancak çalışma kapsamında gerçekleştirilecek testler birkaç aşamayı içeriyorsa büyük ölçüde arttırılabilir (Malhotra 2008; akt. Maiyaki ve Mokhtar 2010: 194). Bu çalışma kapsamında gerçekleştirilecek testler göz önüne alınarak 71 katılımcı üzerinde bir pilot test gerçekleştirilmiştir.

\section{Ortak Yöntem Sapması}

Bu çalışmada olduğu gibi özellikle kullanılan değişkenlerin algisal olduğu durumlarda, araştırmalarda ortak yöntem sapması ile ilgili her zaman endişeler oluşabilmektedir. Bağımlı ve bağımsız değişkenlerin tek bir anket kullanılarak zaman içinde tek bir noktada toplanması hatalara neden olabilmektedir (Chang, van Witteloostuijn ve Eden 2010). Bu çalışmada kullanılan ölçekler, bugüne kadar birçok çalışmada geçerlilik ve güvenilirliği onaylanmış ölçeklerden seçilmiş- 
tir. Ayrıca, çalışmanın örneklem grubuna, cevapların tamamen gizli tutulacağ 1 ve hiçbir şekilde açıklanmayacağı yüz-yüze yapılan görüşmelerde ifade edilmiştir. Bununla beraber, oluşabilecek potansiyel sapmaları önlemek için alanyazında kabul gören bir teknik olan Harman'ın tek faktör testi kullanılmıştır. Bu kapsamda psikolojik sözleşme ihlali, örgütsel özdeşleşme, eşitlik duyarlılığı, duygusal bağlılık ve iş performansını ölçmek için kullanılan tüm maddelerin döngüsüz faktör analizine tabi tutulması gerekmektedir. Bu faktör analizi sonucunda ortak yöntem varyansından (common method variance) söz edebilmek için ilk faktörün varyansın önemli bir bölümünü tek başına açıklaması ya da analiz sonucunda tek faktörün çıkması gerekmektedir (Podsakoff vd. 2003: 889). Mevcut çalışma kapsamında yapılan döngüsüz faktör analizi sonucu, özdeğeri 1'den büyük olan ve toplam varyansların $\% 65$ 'ini oluşturan üç faktör ortaya çıkartmıştır. Birinci faktör, toplam varyansın $\% 25^{\prime}$ ini, ikinci faktör $\% 22,5^{\prime}$ ini ve üçüncü faktör \%17,5'ini oluşturmaktadır. Bu değer toplam varyansın çoğunluğuna karşılık gelmemektedir. Çıkan sonuçlara göre, bu çalışmadaki ortak yöntem sapmasıla ilgili bulguların anlamlı düzeyde olmadığı söylenebilir.

\section{Evren ve Örneklem}

Araştırmanın evrenini, İstanbul ve Antalya illerindeki beş yıldızlı otel işletmelerinin çalışanları oluşturmaktadır. Bu illerin araştırmanın evreni olarak belirlenmesinin nedeni; İstanbul'un şehir otelcili-ğginde, Antalya'nın ise sayfiye turizminde önemli destinasyonlar olmalarıdır. Hazırlanan anket formu bu iller içerinde yer alan 12 adet beş yıldızlı konaklama işletmesinin çalışanlarına uygulanmıştır. Bu çalışmada, örnekleme büyüklü$\breve{g u ̈ ~ i s e ~ t e s a d u ̈ f i ~ o l m a y a n ~(N o n-P r o b a b i l i t y ~ S a m p-~}$ ling) örnekleme yöntemlerinden kolayda örnekleme (Convenience Sampling) yöntemi kullanılarak belirlenmiştir. Bu bağlamda 2017 Ocak-Mart ayları içinde yedi adet İstanbul ve beş adet Antalya illerinde olmak üzere 12 adet beş yıldızlı konaklama işletmesinin çalışanları örneklem olarak seçilmiştir. Araştırmada, konaklama işletmelerine 750 anket formu dağıtılmış, 560 anket formu geri dönmüş ve 15 anket formunun yetersiz/ha- talı doldurulması nedeniyle örneklem sayısı 545 olarak gerçekleşmiştir. \%95 güvenilirlik sınırları içerisinde ve \%5'lik bir hata payı dikkate alınmak koşuluyla 545 katılımcı sayısı araştırma için yeterli görülmüştür. Bu bağlamda anket formlarının geri dönme oranı \%72,66 olarak oranla gerçekleşmiştir. Sektör araştırmalarında genel olarak cevaplama oranı araştırılan konunun içeriğine ve seçilen sektörün özelliklerine bağlı olarak değişmektedir (Dillman 2000; akt. Taşgit vd. 2015: 242). Bu araştırmanın hedef grubu dikkate alındığında anketlerin cevaplanma oranının yeterli olduğu söylenebilir.

\section{BULGULAR}

\section{Tanımlayıcı Bulgular}

Katılımcıların demografik özellikleri ve tanıtıcı bilgiler, üzerinde çalışılan değişkenler de dikkate alınarak şekillenmiştir. Araştırmaya katılanların \%47,3'ü kadınlardan, \%52,7'si ise erkek çalışanlardan oluşmaktadır. Bu katılımcıların \%53,9'u İstanbul'daki beş yıldızlı otellerde, $\% 46,1^{\prime} \mathrm{i}$ ise Antalya'daki beş yıldızlı otellerde çalışmaktadır. Çalışanların \%52,5'i evli iken \%47,5'i bekârdır. Yaş grupları açısından dağılıma bakıldığında, çalışanların yarıdan fazlası 21-35 yaş aralığında $(\% 60,1)$ olup bunu 36-40 yaş aralığında (\%19,3) çalışanlar takip etmektedir. Ayrıca araştırmaya katılanların turizm eğitimi alma durumları ele alındığında \%13,2'sinin turizm lisans mezunu olduğu, \%15,6'sının turizm meslek yüksekokulu mezunu olduğu ve \%37,6'sinın ise turizm lisesi mezunu olduğu görülmektedir. Buna ilaveten katı-lımciların \%26,8'i turizm kurslarıyla turizm eğitimi aldıklarını beyan etmişlerdir. Katılımcıların turizm sektöründe çalışma süreleri incelendiğinde; cevap verenlerin \%36,9'unun 1-6 y1ldır, \%25,3'ünün ise 6-9 yıl arasında tu $\neg$ rizm sektöründe çalışmakta olduğu belirlenmiştir. 10 yıl ve daha fazla deneyime sahip olanların oranı ise \%37,8'dir. Katılımcıların çalıştığı pozisyonlara bakıldığında, \%27,5'i çalışan (işçi), \%38,5'i alt kademe yönetici ve \% 8,6' 1 ise üst kademe yöneticidir.

\section{Ölçüm Modeli}

Modelde yer alan değişkenlerin özellikleri ile ilgili ayrıntılar Tablo 1'de verilmektedir. Ölçüm 
Tablo 1. Modelde Yer Alan Değişkenlerin DFA Sonuçları

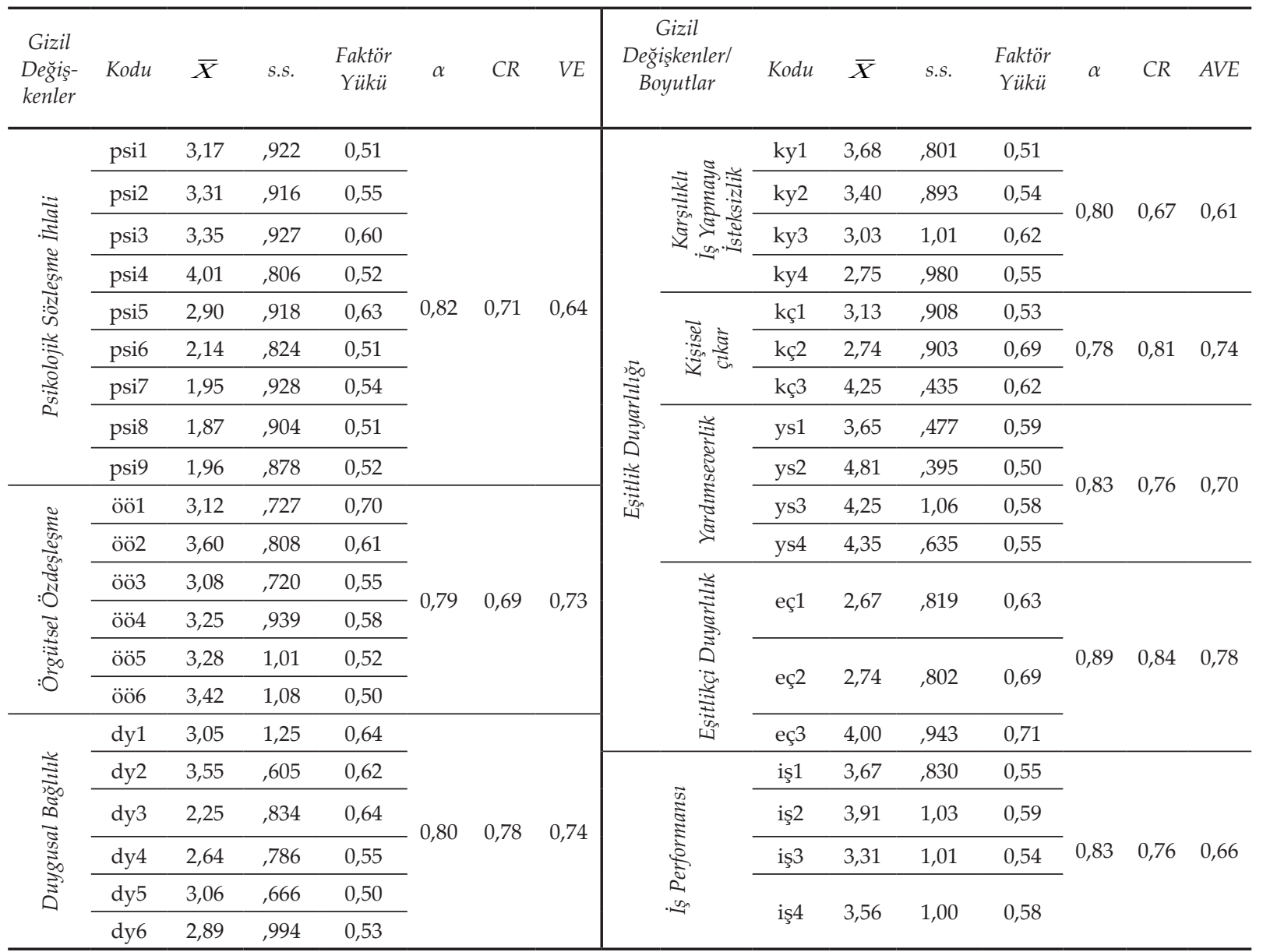

modelini test etmeden önce, her ölçeğin iç güvenilirliğini kontrol etmek için Cronbach alfa katsayılarına bakılmıştır. Tablo 1'de gösterildiği gibi ölçekler ve ölçekleri oluşturan faktörlerin tümü kabul edilebilir değer olarak görülen 0,70'in üzerinde bulunmuştur (Büyüköztürk 2010: 171). Daha sonra, Doğrulayıcı Faktörü Analizi (DFA), ölçüm modelinin geçerliliğini değerlendirmek için kullanılmıştır. Tablo 1'de görüldüğ ü gibi eşitlik duyarlılığını oluşturan ed10 ( = 2,98; faktör yü$k \ddot{u}=0,40)$ ve ed12 $(=4,81$; faktör yükü $=0,29)$ maddelerinin faktör yüklemeleri 0,5 sinırının altında kalmıştır. Bu nedenle bu maddeler modelden ç1karılmış ve değiştirilen ölçüm modeli tekrar test edilmiştir. Tablo 1'de görüldüğü gibi iki maddeyi sildikten sonra, ölçüm modeli iyi bir model uyu$\mathrm{mu}\left(\chi^{2}=319,721 ; \mathrm{df}=120 ; \mathrm{p}=0,000 ; \chi^{2} / \mathrm{df}=2,664\right.$; $\mathrm{GFI}=0,903 ; \mathrm{NFI}=0,945 ; \mathrm{AGFI}=0,913 ; \mathrm{CFI}=0,903$;
RMSEA= 0,041) göstermiştir. Ölçekler ve eşitlik duyarlılı̆̆ının boyutları için birleşik güvenilirlik (CR) kabul edilebilir sınır olan 0,60'ın üzerinde bulunmuştur (Bagozzi ve Yi 1988). Ayrıca açıklanan ortalama varyans (AVE) tahmini her gizil değişken için 0,50 kesme noktasının üzerindedir.

\section{Yapısal Eşitlik Modeli}

Gizil değişkenler arasında kurulan hipotezlere dayalı etkiler ve psikolojik sözleşme ihlalinin iş performansına olumsuz etkisinde eşitlik duyarlılığının aracı rolü tahmini, Yapısal Eşitlik Modelleme (YEM) yaklaşımı kullanılarak, iki model halinde test edilmiştir. İlk modelde gizil değişkenler arasındaki direkt etkilere bakılmış, ikinci modelde ise eşitlik duyarlılığının aracı rolü modele dahil edilmiştir. İlk model için $\chi^{2}=138,498$ ve 73 


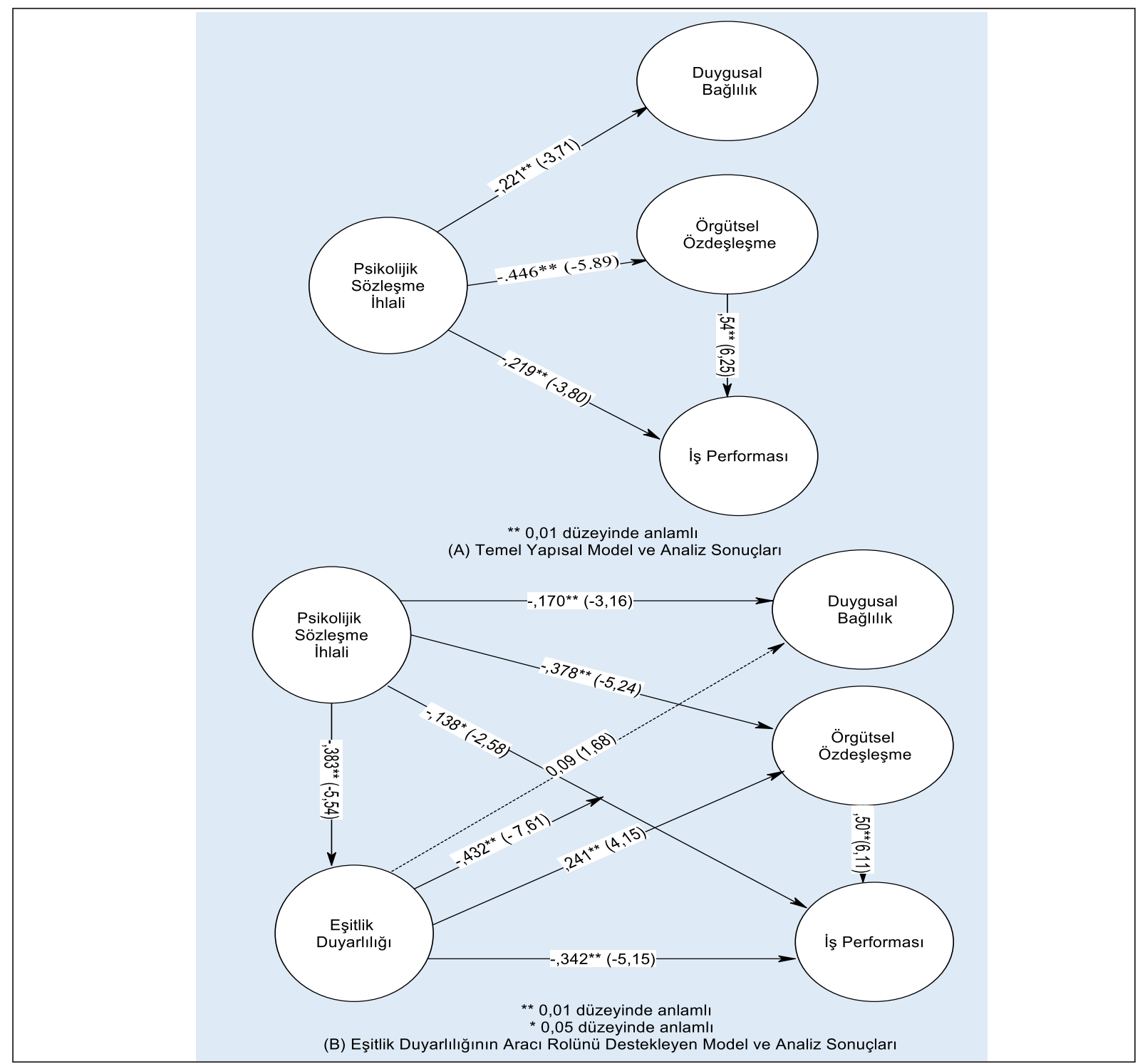

Şekil 2. İki Modelin Standartlaştırılmış Regresyon Katsayıları (Kesik çizgili ok anlamsız yolu göstermektedir. T değerleri parantez içinde verilmişstir).

serbestlik derecesi $\left(\mathrm{p}=0,000 ; \chi^{2} / \mathrm{df}=1,897\right)$ uygun bulunmuştur. Diğer tüm uyum indeksleri, ilk yapısal modelin verilere iyi uyduğunu göstermiştir (GFI $=0,94 ; \mathrm{NFI}=0,93$; AGFI $=0,92 ; \mathrm{CFI}=0,95$; RMSEA=0,047).

Şekil 2A'da sunulduğu gibi temel modelde yer alan gizil değişkenler arasında istatistiksel olarak anlamlı etkilerin var olduğu görülmektedir. Çoklu uyum indeksleri, ikinci modelin de $\left(\chi^{2}=\right.$ 269,646; $\mathrm{df}=127 ; \mathrm{p}=0,000 ; \chi^{2} / \mathrm{df}=2,123 ; \mathrm{GFI}=0,91$; $\mathrm{NFI}=0,96 ; \mathrm{AGFI}=0,92 ; \mathrm{CFI}=0,94 ; \mathrm{RMSEA}=0,051$ ) iyi bir uyum sergilediğini göstermiştir. Eşitlik duyarlılığının aracı rolünü tahmin etmek için kurulan ikinci modelde, psikolojik sözleşme ihlalinin iş performansına olumsuz etkisinin eşitlik duyarlılığının aracı rolü ile olumsuz olarak arttığı görülmektedir (Şekil 2B'ye bakınız). Genel olarak bulgular, kurulan sekiz hipotezden yedisini desteklemiştir.

Temel modelin sonuçları, psikolojik sözleşme ihlalinin duygusal bağlılığı, örgütsel özdeşleşmeyi ve iş performansını olumsuz etkilediğini göstermektedir (H1, H2 ve H6). Ayrıca örgütsel özdeşleşmenin iş performansını olumlu yönde 
etkilediği görülmektedir (H7). Modelin ana öğesi olarak tanımlanan eşitlik duyarlılığı, B modelinde analizlere dahil edilmiştir. Eşitlik duyarlılığı, örgütsel özdeşleşmeyi olumlu yönde ve iş performansını olumsuz yönde etkilemektedir (H3 desteklenmektedir). Ancak eşitlik duyarlı11ğının, duygusal bağlılık üzerinde anlamlı bir etkisinin var olmadığı görülmektedir (H4 hipotezi desteklenmemiştir). Dikkat çeken bir başka çıktı ise psikolojik sözleşme ihlalinin eşitlik duyarlılığı üzerinde önemli bir olumsuz etkisinin varlığıdır (H5). Çalışma kapsamında ayrıca, psikolojik sözleşme ihlalinin iş performansına olumsuz etkisi üzerinde eşitlik duyarlılığının aracı rolü araștırılmıştır. Eşitlik duyarlılığının aracılık etkisi koşullarını sağladığı görülmüştür. Eşitlik duyarlılığ1nın aracı rolü ile psikolojik sözleşme ihlalinin iş performansına etkisinde ortaya çıkan azalmanın anlamlı olup olmadığını saptamak için Sobel testi (Sobel 1982) uygulanmıştır. Sobel Z-skor $=2,475$ ve $p=0,457$ olarak bulunmuştur. Bu bağlamda eşitlik duyarlılığı, psikolojik sözleşme ihlalinin iş performansına olumsuz etkisi üzerinde kısmı aracilık etmektedir denilebilir (H8 hipotezi desteklenmiştir). Bu analizlerin sonuçlarına göre çalışanların eşitlik duyarlılığının artması daha fazla psikolojik sözleşme ihlali algılamalarına neden olmaktadır. Dolayısıyla konaklama işletmelerinin çalışanları arasında eşitlik duyarlılığına dikkat edildiğinde, çalışanların algıladığı psikolojik sözleşme ihlalinin azalacağı ve diğer çalışanlarla karşılaştırdığında kendisinin eşit koşullar altında bulunduğunu gören çalışanın iş performansının artacağ ${ }_{1}$ savı desteklenmektedir.

\section{SONUÇ}

Bu çalışmada, konaklama işletmeleri çalışanlarının psikolojik sözleşme ihlali ve örgütsel özdeşleşme algılarının duygusal bağlılık ve iş performansı üzerindeki etkileri araştırılmakta ve psikolojik sözleşme ihlali ile iş performansı arasındaki ilişkide eşitlik duyarlılığının aracı rolü incelenmektedir. Alanyazında bu konuları birlikte ele alan bir araștırmaya rastlanamamıs olması nedeniyle yürütülen bu çalışma kapsamında elde edilen bulguların alanyazındaki boşluğu kısmen doldurabileceği savunulabilir.
Genel olarak konaklama işletmeleri çalışanlarının psikolojik sözleşme ihlali algıları düşük bulunmuştur. Çalışanlarının psikolojik sözleşme ihlali algıları düşük olan işletmeler, insan sermayesi açısından güçlü konumdadırlar. Çalışanlar eşitlik duyarlılığının 'yardımseverlik' boyutuna 'kişisel çıkarlar' ve 'karşıllıklı iş yapmaya isteksizlik' boyutlarından daha fazla katılım göstermektedirler. Bu sonuç anlık hizmet üreten konaklama işletmelerinde çalışanların iş performansına oldukça olumlu yansıyacak bir sonuçtur. Bu konunun, yönetici ve liderlerin yönetim süreçlerinde önem vermeleri ile işletme başarısında faydalı olacağı düşünülmektedir. Bununla birlikte örgütsel özdeşleşmenin, konaklama işletmeleri çalışanlarının iş performansını artırdığı sonucu, bu çalışmanın önemli çıtılarından biridir. Bu sonuç, Turunç ve Çelik'in (2010: 201) çalışmalarının sonuçlarıyla benzerlik göstermektedir. Örgütüyle özdeşleşen ve kendilerini örgütün bir parçası olarak gören çalışanların işlerin yürütülmesi için daha fazla çaba harcayacakları, içeride ve dışarıda kendilerini örgütün bir temsilcisi olarak görecekleri ve aldıkları bütün kararlarda örgütün menfaatini ön planda tutmaları beklenmektedir (Miller vd. 2000: 652; Turunç ve Çelik 2010).

Öne çıkan sonuçlar arasında beklenildiği üzere, psikolojik sözleşme ihlalinin çalışanların eşitlik duyarlılığını, duygusal bağlılığı, örgütsel özdeşleşme ve iş performansını olumsuz yönde etkilediği tespit edilmiştir. Konaklama işletmeleri çal1şanlarının psikolojik sözleşme algıları ihlal edildiğinde işletmelerine olan duygusal bağlılıkları düşmekte, örgütlerini kendileriyle bir bütün olarak görmemeye başlamakta ve dolayısıyla iş performansları önemli oranda azalmaktadır. Bu çalışmanın sonuçlarıyla benzer olarak Şahin Perçin, Aydın Tükeltürk ve Güzel (2012: 104), konaklama işletmeleri çalışanlarının psikolojik sözleşmelerinin ihlal edildiğine yönelik algıları ile örgüte yönelik duygusal bağlılıkları arasındaki ilişkiyi anlamlı ve olumsuz yönlü olarak etkilediğini tespit etmişlerdir. Bununla birlikte bu çalışmada, eşitlik duyarlılığının duygusal bağlılık üzerinde anlamlı bir etkisinin olmadığı sonucuna ulaşılmıştır.

Ayrıca bu çalışmada, psikolojik sözleşme ihlalinin iş performansına olumsuz etkisi üzerinde 
eşitlik duyarlılığının kısmi aracı rolünün varlığ saptanmıştır. Bu çalışmanın sonuçları çalışanın eşitlik duyarlılı̆̆ arttıkça daha fazla psikolojik sözleşme ihlali algıladığını ortaya koymaktadır. Kısaca eşitlik duyarlılığına dikkat edilen işletmelerde, psikolojik sözleşme algıları ihlal edilmeyen çalışanlar işlerine olumlu duygular taşımakta, çalışanların iş performansı ve örgütsel özdeşleşmesinin artması ile örgütsel hedeflere ve performansa ulaşmaları mümkün olabilmektedir.

\section{Sınırlılıklar ve Gelecek Çalışmalara Yönelik Öneriler}

Bu araştırma, İstanbul ve Antalya illerinde bulunan beş yıldızlı konaklama işletmelerine yöneliktir ve sadece anketle toplanan verilere dayanmaktadır. Çalışma kapsamında yapılacak değerlendirmeler İstanbul ve Antalya ölçeğinde geçerlidir. Diğer konaklama işletmelerine göre beş yıldızlı konaklama işletmeleri daha kurumsal olduğundan, çalışmanın diğer konaklama işletmelerine de uygulanması yerinde olacaktır. Çalışmaya, farklı konu başlıkları eklenerek (örneğin; dinamik yetenekler, inovasyon, iş-aile ve aile-iş çatışması vb.) tekrar çalışılabilir. Farklı illerde, ülkelerde, farklı sektörlerde ve farklı veri toplama araçlarıyla çalışmaların yapılması, sonuçların genelleştirilebilmesi açısından daha sağlıklı bilgiler verebilir.

\section{KAYNAKÇA}

Adams, J. S. (1965). Inequity in Social Exchange. İçinde L. Berkowitz (Editörler), Advances in Experimental Social Psychology (ss. 267-299). Cilt: 2, New York: Academic Press.

Albert, S., Ashforth, B.E. ve Dutton, J.E. (2000). Organizational Identity and Identification: Charting New Waters and Building New Bridges, Academy of Management Review, 25: 13-17.

Allen, N. J. ve Meyer, J. P. (1990). The Measurement and Antecedents of Affective, Continuance and Normative Commitment to the Organization, Journal of Occupational and Organizational Psychology, 63 (1): 1-18.

Ashforth. B. E. ve Mael. F. (1989). Social Identity Theory and The Organization, Academy of Management Review, 14: 20-39.

Ashforth, B.E. Harrison, S.H. ve Corley, K.G. (2008). Identification in Organizations: An Examination of Four Fundamental Questions, Journal of Management, 34 (3): 325-374.

Atalay, D. D. (2007). Denklik Duyarlılı̆̆ı Açısından Algılanan Örgütsel Adalet-Örgütsel Bă̆lanma İlişkisi (Basılmamış Doktora Tezi). Ankara: Ankara Üniversitesi Sosyal Bilimler Enstitüsü.
Bagozzi, R. P. ve Yi, Y. (1988). On the Evaluation of Structural Equation Models, Journal of the Academy of Marketing Science, 16 (1): 74-94.

Bartel, C. A. (2001). Social Comparisons in Boundary-Spanning Work: Effects of Community Outreach on Members, Organizational Identity and Identification, Administrative Science Quarterly, 46: 379-413.

Blau, P.M. (1964). Exchange and Power in Social Life. Transaction Publishers.

Blomme, R.J., Van Rheede, A. ve Tromp, D.M. (2010). The Use of The Psychological Contract to Explain Turnover Intentions in the Hospitality Industry: A Research study on the Impact of Gender on The Turnover Intentions of Highly Educated Employees, International Journal of Human Research Management, 21 (1): 144-162.

Büyüköztürk, Ş. (2010). Sosyal Bilimler İçin Veri Analizi El Kitabı. Ankara: Pegem Akademi.

Chang, S. J., van Witteloostuijn, A. ve Eden, L. (2010). From The Editors: Common Method Variance in International Business Research, Journal of International Business Studies, 41 (2): 178-184.

Conway, N., Guest, D. ve Trenberth, L. (2011). Testing The Differential Effects of Changes in Psychological Contract Breach and Fulfillment, Journal of Vocational Behaviour, 79 (1): 267-276.

Dulac, T., Coyle-Shapiro, J.A.M., Henderson, D.J. ve Wayne, S.J. (2008). Not All Responses to Breach are the Same: The Interconnection of Social Exchange and Psychological Contract Processes in Organizations. Academy of Management Journal, 51 (6): 1079-1098.

Dutton, J. E., Dukerich, J. M. ve Harquail. C. V. (1994). Organizational Images and Member Identification. Administrative Science Quarterly, 39: 239-261.

Epitropaki, O. (2013). A Multi-Level Investigation of Psychological Contract Breach and Organizational Identification Through The Lens of Perceived Organizational Membership: Testing a Moderated-Mediated Model, Journal of Organisational Behaviour, 34 (1): 65-86.

Galvin, B.M., Lange, D. ve Ashforth, B.E. (2015). Narcissistic Organizational Identification: Seeing Oneself As Central To The Organization's Identity, Academy of Management Reiew, 40 (2): 163-181.

Gouldner, A. W. (1960). The Norm of Reciprocity: A Preliminary Statement, American Sociological Review, 25: 161178.

Heskett, J. L., Jones, T. O., Loveman, G. W., Sasser, W. E. ve Schlesinger, L. A. (1994). Putting the Service-Profit Chain to Work, Harvard Business Review, 72 (2): 164170.

Huseman, Richard C., Hatfield, John D. ve Miles, E. W. (1987). A New Perspective on Equity Theory: The Equity Sensitivity Construct, Academy of Management Review, 12 (2): 222-234.

Kickul, J. ve Lester, S. W. (2001). Broken Promises: Equity Sensitivity as a Moderator Between Psychological Contract Breach and Employee Attitudes and Behavior, Journal of Business and Psychology, 16 (2): 191-216. 
Kreiner, G. E. ve Ashforth B. E. (2004). Evidence Toward an Expanded Model of Organizational Identification, Journal of Organizational Behavior, 25: 1-27.

Lester, S.W., Turnley, W.H. ve Bloodgood, J.M. (2000). Supervisor and Subordinateviews of Psychological Contract Fulfillment: The Impact of Perceptual Differences on Employee Work Attitudes and Behaviors. In: Proceedings of the Academy of Management Proceedings, ss. C1C6.

Li, J. J., Wong, I. A. ve Kim, W. G. (2016). Effects Of Psychological Contract Breach On Attitudes Andperformance: The Moderating Role Of Competitive Climate, International Journal of Hospitality Management, 55: 1-10.

Lub, X., Nije Bijvank, M., Matthijs Bal, P., Blomme, R. ve Schalk, R. (2012). Different or Alike? Exploring the Psychological Contract and Commitment of Differentgenerations of Hospitality Workers, International Journal of Contemporary Hospitality Management, 24 (4): 553-573.

Mael, F. ve Ashforth, B. (1992). Alumni and Their Alma Mater: a Partial Test of The Reformulated Model of Organizational Identification, Journal of Organizational Behavior, 13 (2): 103-123.

Mael, F. ve Tetrick, L.E. (1992). Identifying Organizational Identification, Educational and Psychological Measurement, 52: 813-824.

Maiyaki, A. A. ve Mokhtar, S. S. M. (2010). Determinants of Customer Behavioural Responses: A Pilot Study, International Business Research, 4 (1): 193-197.

Miller, V.D., Allen, M., Casey M.K. ve Johnson, J.R. (2000). Reconsidering the Organizational Identification Questionnaire, Management Communication Quarterly, 13 (4): 626-658.

Morrison, E.W. ve Robinson, S.L. (1997). When Employees Feel Betrayed: A Model Of How Psychological Contract Violation Develops, Academy of Management Review, 22 (1): 226-256.

Podsakoff, P.M., Mackenzie, S.B., Podsakoff, N.P. ve Lee, J.-Y. (2003). Common Method Biases in Behavioral Research: A Critical Review of the Literature and Recommended Remedies, Journal of Applied Psychology, 88 (5): 879-903.

Raja, U., Johns, G. ve Ntalianis, F. (2004). The Impact of Personality on Psychological Contracts, Academy of Management Journal, 47 (3): 350-367.

Robinson, S. L. ve Morrison, E. W. (2000). The Development of Psychological Contract Breach and Violation: A Longitudinal Study, Journal of Organizational Behavior, 21 (5): 525-546.

Rousseau, D. M. ve Greller, M. M. (1994). Human Resource Practices: Administrative Contract Makers, Human Resource Management, 33 (3): 385-401.

Şahin Perçin, N., Aydın Tükeltürk, Ş. ve Güzel, B. (2012). Psikolojik Kontrat İhlal Algısı İle Örgütsel Bağlılık İlişkisi:
Otel İşletmeleri Üzerine Bir Araştırma, Yönetim Bilimleri Dergisi, 10 (20): 93-110.

Shih, C.T. ve Chuang, C.H. (2013). Individual Differences, Psychological Contract Breach, and Organizational Citizenship Behavior: A Moderated Mediation Study. Asia Pacific Journal of Management, 30 (1): 191-210.

Shore, L.M. ve Barksdale, K. (1998). Examining Degree of Balance and Level of Obligation in The Employment Relationship: A Social Exchange Approach, Journal of Organizational Behavior, 19: 731-744.

Sigler, T. H. ve Pearson, C. M. (2000). Creating an Empowering Culture: Examining The Relationship Between Organizational Culture and Perceptions of Empowerment, Journal of Quality Management, 5 (1): 27-52.

Sobel, M. E. (1982). Asymptotic Confidence Intervals For Indirect Effects in Structural Equation Models, Sociological Methodology, 13: 290-312.

Suazo, M., Turnley, M. ve Mai-Dalton, R. (2005). Antecedents of Psychological Contract Breach: The Role of Similarity and Leader-Member Exchange, Academy of Management Annual Meeting Proceedings, 5-10 Ağustos, Honolulu, Hawaii.

Taşgit, Y. E., Çömlekçi, İ. ve Öncü, M. A. (2015). Beş Yıldızlı Otel İşletmelerinde Entelektüel Sermayenin Belirleyicileri: Yöneticilerin Bakış Açısına Dayanan Bir Değerlendirme. Anatolia: Turizm Araştırmaları Dergisi, 26 (2): 238-250.

Tekleab, A.G., Takeuchi, R. ve Taylor, M.S. (2005). Extending The Chain of Relationships Among Organizational Justice, Social Exchange, And Employee Reactions: The Role of Contract Violations, Academy of Management Journal, 48 (1): 146-157.

Turnley, W.H., Bolino, M.C., Lester, S.W. ve Bloodgood, J.M., (2003). The Impact of Psychological Contract Fulfillment on the Performance of In-Role and Organizational Citizenship Behaviors, Journal of management, 29 (2): 187-206.

Turunç, Ö. ve Çelik, M. (2010). Çalışanların Algıladıkları Örgütsel Destek ve İş Stresinin Örgütsel Özdeşleşme ve İş Performansına Etkisi, Yönetim ve Ekonomi, 17 (2): 183206.

Van Dick, R. (2004). My Job is My Castle: Identification in Organizational Contexts, International Review of Industrial and Organizational Psychology, 19: 171-203.

Van der Vegt, G. S., Van de Vliert, E. ve Oosterhof, A. (2003). Informational Dissimilarity and OCB: The Role of Intrateam Interdependence and Team Identification, Academy of Management Journal, 46 (6): 715-727.

Wu, C. M. ve Chen, T. C. (2015). Psychological Contract Fulfillment in the Hotel Workplace: Empowering Leadership, Knowledge Exchange, and Service Performance, International Journal of Hospitality Management, 48: 27-38. 


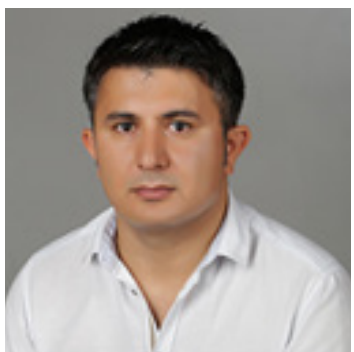

\section{Bekir EȘíTTí}

Erciyes Üniversitesi Turizm İşletmeciliği ve Otelcilik Yüksekokulu'ndan mezun oldu (2005). Yüksek lisans derecesini Wales Institute Cardiff Üniversitesi İşletme Yönetimi Anabilim dalından (2008), doktora derecesini ise Çanakkale Onsekiz Mart Üniversitesi Turizm İşletmeciliği Anabilim Dalından aldı (2016). Aksaray Üniversitesi Otel Lokanta ve İkram Hizmetleri Bölümünde çalışmaya başladı (2013). Halen Çanakkale Onsekiz Mart Üniversitesi Seyahat İşletmeciliği ve Turizm Rehberliği Bölümü'nde görev yapmaktadır. Temel çalışma alanları; Turizm İşletmeciliği, Davranış Bilimleri ve Turizm Yönetimi'dir. 